\section{Az önkormányzatok és a nonprofit szektor kapcsolata a pécsi kistérség példáján}

\section{Bevezetés}

A nonprofit szervezetek jelentős része települési szinten müködik. A település lakosságának érdekeit, céljait, az alulról jövő kezdeményezéseket képviseli, így ezek a közösségek együttműködő partnerei lehetnek a települési önkormányzatoknak. A szektor szervezetei az önkormányzatok számára jelezhetik a településeken lakók társadalmi igényeit, problémáit, szükségleteit, segíthetik munkájukat, feladatokat vállalhatnak át, egyfajta összekötő szerepet tölthetnek be a lakosság és az önkormányzatok között.

Az önkormányzatok és a civil szervezetek számára a rendszerváltozás óta eltelt másfél évtized elegendőnek bizonyult arra, hogy rájöjjenek együttműködésük fontosságára és sikerességére. Egymásra találásuk mindkét fél érdeke. Másrészt az önkormányzatok számára törvény ${ }^{1}$ mondja ki a helyi társadalom közösségeinek támogatását. Emellett hasonlóan fontos a nonprofit szervezetek önkormányzati szövetségekbe, társulásokba való bevonása, hiszen a térségfejlesztésben elengedhetetlenül fontos szerepet töltenek be ezek a települési kapcsolatok. Azonban bármennyire ismert a két szektor egymásra utaltsága, az önkormányzatok csak lassan válnak nyitottá a civilek felé.

Az önkormányzatok feladatai az évek során folyamatosan gyarapodtak, azonban az ellátásukhoz rendelkezésre álló pénz nem nőtt, hanem csökkent. Az anyagi forráshoz képest túlméretezett a feladatok köre. (Gáspár M. 1999) Ezért kézenfekvő megoldás lenne ezeket a feladatokat átadni olyan civil szervezeteknek, akik képesek megoldani őket. Hiszen ha a nyugati példákat nézzük, akkor a nyolcvanas évek végén az állam megkezdte kivonulását a jóléti ellátási szférából és ezeket a szerepeket átadta a civil szervezeteknek. Ezt a nyugat-európai országok azért tehették meg, mert a civil szektor igen erős hagyományokkal rendelkezik, és rábízhatók ezek a feladatok. (Katona P. 1999) Az önkormányzatokkal való együttműködés kulcsa az egymás iránti bizalom és a partnerség. Ez elengedhetetlen feltétele annak, hogy az önkormányzat egyenrangú félként tudja kezelni a harmadik szférát. Gyakran a szervezetekkel szembeni bizalmatlanság, az ismeretek hiánya jellemzi az önkormányzatokat, és ez lesz a legfőbb gátja a két szektor közötti együttműködés sikerességének.

\section{A pécsi kistérség és nonprofit szervezetei}

A kistérség hazánk legdélibb megyéjében, Baranyában található, a Dél-Dunántúl meghatározó jelentőségủ vidéke, amit leginkább centrális helyzetének és Pécsnek köszönhet. A vizsgált kistérség esetében a KSH által lehatárolt és az önkormányzatok által létrehozott Pécs és Környéke Önkormányzati Területfejlesztési Társulás területe egybeesik. ${ }^{2} \mathrm{~A}$ kistérség Pécs városát és annak agglomerációját is magában foglalja, a Mecsek hiegység vonulatát követve helyezkedik el. A települések vonatkozásában meghatározó jelentőségü Pécs városa. A 39 település a 6-os fő́közlekedési útról leágazva helyezkedik el. Jellemzóen aprófalvak alkotják, melynek egyetlen városa Pécs Megyei Jogú Város, mely meghatározó jelentőségü, regionális kihatással bír. A város közel 160000 fős népessége egészül ki a környékbeli községek megközelítőleg 26000 fős népességével. A környező települések $60 \%$-a 500 főnél kisebb törpefalu, Baranya megye minden ötödik ilyen községe ebben a kistérségben található. A többi $40 \% 500$ főnél nagyobb, de 2000 Iônél kisebb, csupán egy település népessége haladja meg a 4000 főt, a Pécstől $5 \mathrm{~km}-\mathrm{re}$ található Kozármislenyé. A kistérség lakosainak $53,13 \%$-a nő és 46,87\%-a férfi, ezen belül ażonban a települések között nagy eltérések tapasztalhatók.

1. táblázat: A Pécsi kistérség településeinek lakónépessége, 2003

\begin{tabular}{|l|r|l|r|l|r|}
\hline Település & $\begin{array}{c}\text { Lakosság szám } \\
\text { (fö) }\end{array}$ & \multicolumn{1}{|c|}{ Település } & $\begin{array}{c}\text { Lakosság szám } \\
\text { (fö) }\end{array}$ & \multicolumn{1}{|c|}{ Település } & $\begin{array}{c}\text { Lakosság szám } \\
\text { (fó) }\end{array}$ \\
\hline Abaliget & 637 & Keszü & 1024 & Pellérd & 1984 \\
\hline Aranyosgadány & 363 & Kisherend & 208 & Pogány & 1083 \\
\hline Áta & 230 & Kovácsszénája & 55 & Regenye & 180 \\
\hline Bakonya & 401 & Kozármisleny & 4247 & Romonya & 423 \\
\hline Baksa & 765 & Kökény & 566 & Szalánta & 1178 \\
\hline Birján & 444 & Kővágószöllös & 1343 & Szemely & 457 \\
\hline Bogád & 842 & Kővágótöttös & 314 & Szilvás & 194 \\
\hline Bosta & 143 & Lothárd & 269 & Szőke & 168 \\
\hline Cserkút & 430 & Magyarsarlós & 339 & Szőkéd & 401 \\
\hline Egerág & 1004 & Nagykozár & 1387 & Tengeri & 75 \\
\hline Ellend & 230 & Ócsárd & 430 & Téseny & 322 \\
\hline Görcsöny & 1726 & Orfü & 761 & & \\
\hline Gyód & 618 & Pécs & 158942 & & \\
\hline Husztót & 65 & Pécsudvard & 644 & Összesen & $\mathbf{1 8 4} \mathbf{8 9 2}$ \\
\hline
\end{tabular}

Forrás: KSH, Baranya megyei Statisztikai évkönyv, 2002

A kistérség népsürűsége 320 fö/km². Pécs Megyei Jogú Város nélkül számítva ez az érték 44 fö/ $/ \mathrm{km}^{2}$, ami jelentősen elmarad az amúgy is alacsony megyei átlagtól (90fö/ $\left.\mathrm{km}^{2}\right)$, sőt a Dél-Dunántúl statisztikai régió átlagától is (69fö/ $\left.\mathrm{km}^{2}\right)$.

A Központi Statisztikai Hivatal (későbbiekben KSH) T-STAR adatbázisának leválogatása alapján 2004-ben a Pécsi Kistérség területén 1553 nonprofit szervezet működött. Ami azt jelenti, hogy a Baranya megyében található nonprofit szervezetek több mint kétharmada a vizsgált területen található. 


\begin{tabular}{|c|c|c|c|c|c|}
\hline \multirow[t]{2}{*}{ Település } & \multicolumn{2}{|c|}{ Nonprofit szervezetek } & \multirow[t]{2}{*}{ Település } & \multicolumn{2}{|c|}{ Nonprofit szervezetek } \\
\hline & $\begin{array}{l}\text { Száma } \\
(\mathrm{db})\end{array}$ & $\begin{array}{c}1000 \text { lakosra } \\
\text { jutó }\end{array}$ & & $\begin{array}{l}\text { Száma } \\
(\mathrm{db})\end{array}$ & $\begin{array}{l}1000 \text { lakosra } \\
\text { jutó }\end{array}$ \\
\hline Abaliget & 9 & 14,1 & Kővágótöttős & 1 & 3,1 \\
\hline Aranyosgadány & 0 & 0 & Lothárd & 0 & 0 \\
\hline Áta & 1 & 4,3 & Magyarsarlós & 1 & 2,9 \\
\hline Bakonya & 3 & 7,3 & Nagykozár & 4 & 2,8 \\
\hline Baksa & 8 & 10,4 & Ócsárd & 2 & 4,6 \\
\hline Birján & 2 & 4,5 & Orfü & 9 & 11,8 \\
\hline Bogád & 3 & 3,5 & Pécs & 1417 & 8,9 \\
\hline Bosta & 0 & 0 & Pécsudvard & 4 & 6,2 \\
\hline Cserkút & 5 & 11,6 & Pellérd & 11 & 5,7 \\
\hline Egerág & 7 & 6,9 & Pogány & 9 & 8,3 \\
\hline Ellend & 0 & 0 & Regenye & 1 & 5,5 \\
\hline Görcsöny & 4 & 2,3 & \begin{tabular}{|l|} 
Romonya \\
\end{tabular} & 1 & 2,3 \\
\hline Gyód & 2 & 3,2 & \begin{tabular}{|l|} 
Szalánta \\
\end{tabular} & 5 & 4,2 \\
\hline Husztót & 1 & 15,3 & Szemely & 1 & 2,1 \\
\hline Keszü & 1 & 0,97 & Szilvás & 0 & 0 \\
\hline Kisherend & 1 & 4,8 & Szőke & 0 & 0 \\
\hline Kovácsszénája & $3^{5}$ & 54,5 & Szökéd & 0 & 0 \\
\hline Kozármisleny & 23 & 5,4 & Tengeri & 0 & 0 \\
\hline Kökény & 4 & 7,0 & Téseny & 0 & 0 \\
\hline Kővágószöllős & 10 & 7,4 & Összesen & 1553 & 8,3 \\
\hline
\end{tabular}

Forrás: KSH T-STAR leválogatás.

A szervezetek ilyen nagy számban és sűrüségben történő megjelenése hazánkban ezen kívül csak két nagy történelmi múlttal és regionális szerepkörrel bíró megyeszékhelyünkön fordul elő, ezek Debrecen és Szeged. A kistérségben müködő szervezetek 91\%-a a megyeszékhelyen, 9\%-a a községekben múködik. Kilenc településen nincs bejegyzett, intézményesült nonprofit szervezet, ez a községek $23 \%$-át, a települések 25\%-át teszi ki. A kérdőíves vizsgálat során az önkormányzatok részéről visszaérkezett adatok alapján 10 olyan település van, ahol nincs civil aktivitás és szervezet. $\mathrm{Az}$ a tény, hogy a környező települések közel egynegyedén formális szervezet nem müködik, jelentős eltérést mutat az országos adatoktól, ahol a települések 16\%-ára jellemző ez az ismérv. Következtethetünk ebből arra, hogy vagy nagyon gyenge a helyi lakosság önszerveződő képessége, vagy informális közösségek működnek elsősorban ezekben a községekben, esetleg a helyi lakosság más településen müködő nonprofit szervezetnek a tagja. Ez utóbbi esetben számít a település térbeli közelsége, az ingázók esetében a munkahely településén működő szervezeti lehetőség, a települések közötti meglévő gazdasági, kulturális, családi és baráti kapcsolatok. A szervezettel nem rendelkező települések kivétel nélkül a kistérség perifériáján találhatók, Pécs agglomerációján kívül a Siklósi és a Sellyei kistérség határához esnek közel. Ezek a települések 500 lélekszám alattiak, alacsony népességmegtartó képességgel rendelkeznek, lakosaik társadalmi, gazdasági, szociális problémákkal küzdő idős emberek. Az önszerveződések méréséhez és összehasonlításához az abszolút számokon túl az
1000 lakosra jutó szervezetszámot kell megvizsgálnunk. A mutatók alapján elmondható, hogy a pécsi kistérség nonprofit szférája igen erős, nagy számú szervezettel bír, az országos és a Baranya megyei átlagot jelentősen meghaladja. ${ }^{5}$ A községekben és Pécsen a szféra számosságát és aktivitását tekintve is kedvezőbb a kép, mint az azonos településtípusra számított országos átlag (község 3,4, megyeszékhely 6,1). A 3. táblázut adatait nézve a települések több, mint felében az ezer lakosra jutó szervezetszám meghaladja a községekre jellemző átlagot, $43 \%$-a az országos átlagot.

3. táblázat: 1000 lakosra jutó szervezetszám a településeken, 2004

\begin{tabular}{|c|c|c|}
\hline $\begin{array}{l}1000 \text { lakosra jutó szer- } \\
\text { vezetszám kategóriák }\end{array}$ & $\begin{array}{c}\text { Települések } \\
\text { száma }\end{array}$ & Települések nevei (1000 lakos/szervezetszám) \\
\hline 0 & 9 & $\begin{array}{l}\text { Aranyosgadány, Bosta, Ellend, Lothard, Szilvás, Szőke, Szőkéd, } \\
\text { Tengeri, Téseny }\end{array}$ \\
\hline $1-5$ & 14 & $\begin{array}{l}\text { Ata }(4,3) \text {, Birján }(4,5) \text {, Bogád }(3,5) \text {, Görcsöny }(2,3) \text {, Gyód }(3,2) \text {, } \\
\text { Keszü }(0,9) \text {, Kisherend }(4,8) \text {, Kövágótöttös }(3,1) \text {, Magyarsarlós } \\
(2,9) \text {, Nagykozár }(2,8) \text {, Ócsárd }(4,6) \text {, Romonya }(2,3) \text {, Szalánta }(4,2) \text {, } \\
\text { Szemely }(2,2)\end{array}$ \\
\hline $5,1-10$ & 10 & $\begin{array}{l}\text { Bakonya (7,3), Egerág (6,9), Kozármisleny }(5,4) \text {, Kökény }(7,0) \text {, } \\
\text { Kővágószöllós }(7,4) \text {, Pécs }(8,9) \text {, Pécsudvard }(6,2) \text {, Pellérd }(5,7) \text {, Po- } \\
\text { gány }(8,3) \text {, Regenye }(5,5)\end{array}$ \\
\hline $10,1-15$ & 4 & Abaliget $(14,1)$, Baksa $(10,4)$, Cserkút $(11,6)$, Orfü $(11,8)$ \\
\hline $15,1-20$ & 1 & Husztót $(15,4)$ \\
\hline $20,1-$ & 1 & Kovácsszénája $(54,5)$ \\
\hline Ósszesen & 39 & \\
\hline
\end{tabular}

Forrás: KSH T-STAR adatbázis leválogatása alapján

\section{A kutatás nehézségeiről és a felhasznált kutatási módszerekről}

A tanulmány részét képezi egy 2005 első félévében folytatott kutatásnak, mely a pécs kistérség teljes nonprofit szektorát térképezte fel, hogy annak bemutatásával átfogó képet adjon a térség életében, fejlődésében szerepet játszó nonprofit szervezetek helyzetéről, jellegzetességéről, feltárja a szervezetek szerepét, lehetőségeit, társadalmi beágyazottságát, a helyi társadalom szereplőivel való viszonyát (helyi önkormányzattal, a kistérségi társulással, médiával). A kutatást a Nemzeti Civil Alapprogramon belül a Civil Szolgáltató, Fejlesztő és Információs Kollégium finanszírozta.

A tanulmányban kérdőívek, célzott interjúk, települési dokumentumok kritikai elemzése segítségével keresünk választ a településeken tapasztalható különbségekre, az önszerveződés létének vagy hiányának okára, a motivációkra vagy gátló tényezőkre. Statisztikai adataink elsősorban a Központi Statisztikai Hivatalból, a T-STAR válogatásából, a Civil Szolgáltató Központ adattárából származnak. Az interjúkat a térség nonprofit szférájának meghatározó személyeivel, civil szervezetek vezetőivel és tagjaival készítettük. 
A kérdőíveket postai úton juttattuk el a mintában szereplő 636 nonprofit szervezetnek és a 39 települési önkormányzatnak. A pécsi nonprofit szervezetek egyharmada kapott kérdőívet (500 darab), míg a környező települések összes, mind a 136 szervezetéhez eljutott a felmérés.

A mintába a nonprofit szervezetek az alapsokaság tevékenységi szerkezete, illetve szervezeti forma szerinti százalékos megoszlásának megfelelően kerültek. A vizsgálat során az volt a cél, hogy az önkormányzati és a nonprofit oldal is megvilágításba kerüljön.

A nonprofit szervezeteknek kiküldött kérdőívek közel egynegyede érkezett vissza. A válaszadási hajlandóság a községekben múködő szervezetek esetében magasabb volt, közel egyharmaduk küldte vissza a kitöltött kérdőívet. Az önkormányzatok oldaláról sokkal nagyobb volt az adatszolgáltatási kedv, hiszen több mint $60 \%$-uk részt vett a kutatásban.

\section{Önkormányzatok és nonprofit szervezetek kapcsolata a pécsi kistérségben}

Az önkormányzatok részéről talán a legelső lépés a nonprofit szervezetek felé a településen tevékenykedő szervezetek számbavétele, megismerése. Kilenc önkormányzat jelezte vissza, hogy nincs nyilvántartása, mert tudomása szerint nem múködik a községben nonprofit szervezet. Bakonyának nincs nyilvántartása, bár hat szervezet is létezik a településen. A fennmaradó 14 településen működik öntevékeny szervezet és minden esetben van nyilvántartás a szervezetekről. Ennek nehézségeiről az önkormányzatok is beszámoltak, hiszen nehéz követni a megalakuló, megszünő szervezeteket. A községek esetében sok helyen elhangzott az a két mondat, hogy „amiről mi nem tudunk, az nem múködik”, illetve „mi csak arról tudunk, akivel kapcsolatban állunk". A kisebb községek esetében a személyes kapcsolatok miatt a nyilvántartás sokszor csak a fejekben létezik, nem papíron.

4. táblázat: Pécsi kistérség önkormányzatinak nyilvántartása a térség nonprofit szervezeteiröl, 2004

\begin{tabular}{|c|c|c|}
\hline $\begin{array}{c}\text { Nyilvántartott nonprofit szervezetek } \\
\text { száma }\end{array}$ & $\begin{array}{c}\text { Települési önkormányzatok } \\
\text { száma }\end{array}$ & Települési önkormányzatok \% \\
\hline Nincs nyilvántartása & 10 & 41,6 \\
\hline 1 & 3 & 12,5 \\
\hline 2 & 2 & 8,3 \\
\hline 3 & 2 & 8,3 \\
\hline 5 & 2 & 8,3 \\
\hline 8 & 1 & 4,2 \\
\hline 10 & 2 & 8,3 \\
\hline 13 & 1 & 4,2 \\
\hline 425 & 1 & 4,2 \\
\hline Összesen & 24 & 100,0 \\
\hline
\end{tabular}

Forrás: kérdöíves vizsgálat

36
Az önkormányzat és a nonprofit szervezetek közötti kapcsolattartás és egyeztetés legegyszerűbb módja, ha az önkormányzat civil referenst alkalmaz. Azonban ez még kevéssé elterjedt. A főállású alkalmazás nagyon ritka, a településeken általában felvett feladatként töltik be a szerepkört. Pécsnek főállású referense van erre a feladatfa, aki kapcsolatot tart a város egyesületeivel, alapítványaival. 11 község ${ }^{6}$ egyáltalán nem alkalmaz olyan személyt, aki ezt a feladatkört betöltené. 10 település esetében a polgármester az a személy, aki a kapcsolatot tartja. A kistérségben tapasztalható hielyzet az országos állapotnak megfelelő, hiszen civil referens foglalkoztatása csak a városokra, azok közül is a megyeszékhelyekre jellemző. Azokon a településeken, ahol mégis fontosnak érzik a civil referens alkalmazását, általában a pályázati forrásokból oldják meg a foglalkoztatását, azonban a kistérségre ez nem jellemző.

5. táblázat: Az önkormányzat rendelkezik-e kapesolattartó személlyel, 2004

\begin{tabular}{|l|c|c|}
\hline Kapesolattartó & Önkormányzatok száma & Önkormányzatok \% \\
\hline Nines kapcsolattartó személy & 11 & 45,8 \\
\hline Van, ez a polgármester & 10 & 41,6 \\
\hline Van kapcsolt munkakörben & 1 & 4,2 \\
\hline Van a mủvelődési ház & 1 & 4,2 \\
\hline Civil referens & 1 & 4,2 \\
\hline Osszesen & 24 & 100,0 \\
\hline
\end{tabular}

Forrás: kérdốves vizsgálat

A kutatók, a politikusok és a nonprofit szervezetek között állandó vitatémává vált annak kérdése, hogy az önkormányzat működésében, a döntések előkészítésében és magában a döntési folyamatban részt kell-e venniük a civil szervezeteknek. A kutatók véleménye szerint indokolt lenne a szervezetek szerepe ebben a témában, de ezt a đöntéshozatali kérdések kinyitásával és társadalmasításával tartják elképzelhetőnek. Másrészt ha a civil szervezetek bekerülnek a képviselő-testületbe, az nehezen ôsszeegyeztethető a politikamentességgel és céljaikkal, főképp abban az esetben, ha a képviselő testületekben a mérleg nyelve szerepet töltik be. A helyi politikusok szerint a lakosság őket választotta meg a település ügyeinek irányítására. A nonprofit nzervezetek szerint a testületi munka gyakran esik a pártpolitika áldozatává, és ezen a civil szervezetek jelenléte segíthet. (Csegény-Kákai, 2001; 59) 


\begin{tabular}{|l|c|c|c|c|}
\hline \multicolumn{1}{|c|}{ Kapesolat formája } & \multicolumn{2}{|c|}{$\begin{array}{c}\text { Nonprofit szervezetek a Pécsi } \\
\text { kistérség területén, akik, a } \\
\text { megnevezett kapcsolati for- } \\
\text { mában jelen vannak }\end{array}$} & $\begin{array}{c}\text { Onkormányzatok száma, akik } \\
\text { a megnevezett kapcsolati for- } \\
\text { mában kapcsolatot tartanak } \\
\text { nonprofit szervezetekkel }\end{array}$ \\
\cline { 2 - 5 } & száma & $\%$ & száma & $\%$ \\
\hline $\begin{array}{l}\text { Az önkormányzati ülésekre meghívót kap- } \\
\text { nak az önkormányzattól, ha az adott témá- } \\
\text { ban érdekeltek. }\end{array}$ & 36 & 24,8 & 9 & 37,5 \\
\hline $\begin{array}{l}\text { Szerepet kapnak a településsel kapcsolatos } \\
\text { ügyek megvitatásában, tanácskozási joggal } \\
\text { bírnak. }\end{array}$ & 17 & 11,7 & 4 & 16,7 \\
\hline $\begin{array}{l}\text { Az önkormányzat elözetes véleményezésre } \\
\text { elöterjesztéseket küld. }\end{array}$ & 13 & 9,0 & 4 & 16,7 \\
\hline $\begin{array}{l}\text { Az Önök civil szervezetének képviselöje } \\
\text { részt vesznek az egyes szakbizottságok mun- } \\
\text { káiban. }\end{array}$ & 13 & 9,0 & 14 & 58,3 \\
\hline $\begin{array}{l}\text { Az önkormányzattal együtt nyújtanak be } \\
\text { közös pályázatot. }\end{array}$ & 9 & 6,2 & 5 & 20,8 \\
\hline $\begin{array}{l}\text { Nem tartanak igényt az Önök, munkájára, } \\
\text { segítségére az önkormányzati munka terén. }\end{array}$ & 96 & 66,2 & 0 & 0 \\
\hline
\end{tabular}

Forrás: kérdőives vizsgálat

A kérdőíves vizsgálat és az interjúk segítségével képet kaphatunk a kistérségben található települési önkormányzatok és szervezetek közötti együttműködés létéről az önkormányzati munkában. A civil szervezetek oldaláról nézve csak részlegesen létezik kapcsolat és összekötổ szerep, hiszen a szervezetek több mint kétharmada úgy érzi, hogy az önkormányzat semmilyen formában nem számít a tevékenységére. Ugyanakkor tudjuk, hogy milyen fontos lenne a közös munka és egymás segítése a helyi feladatok ellátásában. Az önkormányzat kevés esetben hívja meg a szervezeteket az önkormányzati ülésekre, a szakbizottságok munkájában való részvételre. Az önkormányzatok oldaláról nézve, jelen helyzetben legitimebbnek érzik a helyüket és szerepüket a helyi társadalom életében. A társadalom jelentős része sajnos még nincs tudatában annak, hogy a képviseleti demokráciában a képviselők megválasztásán kívül szervezetekbe tömörülve lehetőségük és joguk van a helyi ügyek véleményezésére, megvitatására.

A térség néhány önkormányzata már tisztában van az együttműködés pozitívumaival és partnereket lát a nonprofit szervezetekben. Ezek között szerepel példamutatóként Pécs, ahol több éve formálódik a kapcsolat és igen erős, aktív civil szféra alakult ki. Hasonló módon kiemelhető Bakonya, Pellérd, Szalánta, Cserkút és Orfü.

A szervezetek a kistérség területén javarészt anélkül akarnak részt venni a helyi ügyek formálásában, hogy közvetlenül választott önkormányzati képviselőik lennének. Az önkormányzati ülésekre Pécsett a szervezetek egynegyede kap meghívót, a községi szervezetek több mint fele. A községek helyzete a kistérségben jobb a kapcsolatkiépítés és annak elmélyítése esetében. A nonprofit szervezetek száma ezeken a településeken 5-10 körüli, a lakosság alacsony számú, így könnyebb az érdekeket és elképzeléseket egymáshoz közelíteni. A szerepkörök sok esetben összefolynak.

Arâmos esetben a telepúléseken található szervezetek tagjai nem csak a civil élethen, hanem a települési politikában?, a képviselötestületi munkában is aktív szerepet vallalnak. Kiemelt szerepet játszanak a települések azon személyei, akik jelentős társadalmi tőkével, közösségi szemlélettel bírnak. A települések jelentős többségében ezeken a személyeken múlik a helyi közösségek létrejötte és munkája. A községek lakónépessége alapján a 250 és 500, az 1000 és 1500 valamint az 1500 és 2500 közötti népességgel rendelkező települések fele meghívja az ügyben érintett civil szervezetet iz önkormányzati ülésekre.

A nonprofit szervezetek szemszögéből nézve a döntés-előkészítő feladatokban való részvétel ritka és semmiképp sem jellemző. Ebben az esetben nem találhiutunk településméretek alapján különbségeket. A községekben működő nonprofit mervezetek helyzete a kistérségben az országos átlagnak megfelelő, viszont a pécsi nervezetek esetében jelentős az elmaradás. A KSH 1996-os felmérése alapján a megyeszékhelyeken tevékenykedő szervezetek több, mint 90\%-a részt vesz a döntések elokészítésében.

A szakbizottságok munkájába az önkormányzatok fele bevonja a civil szervereteket, a községekben ez a szám alig haladja meg a 10\%-ot. A községekben a civil wiéra részvételének esélye korlátozott, hiszen több esetben nincsenek bizottságok, illetve alacsony a számuk. A pécsi önkormányzat 2002 óta működteti az Ifjúsági és Civil Kapcsolatok Bizottságát, mely segíti az együttműködést a két fél között, többek között anyagi támogatást, érdekképviseletet nyújt a szervezetek számára, ellenőrzi az îtudott feladatkörök hatékony ellátását.

Az önkormányzatok és a szervezetek közötti kapcsolat egyik megjelenési formajja, ha az önkormányzat pályázatot ír ki, illetve együtt pályázik a nonprofit szerveıettel. A közösen benyújtott pályázatok száma a nagyobb lélekszámmal rendelkezô településnagyság irányában növekszik. A pályázatok számát nézve megállapítható, hogy összefüggés van a pályázatbeadások között és az önkormányzatok által alapított kỏzalapítványok száma, valamint a kapcsolattartó személy léte között.

Pécs esetében a nonprofit szféra és önkormányzat együttműködése nem tekinthető zökkenőmentesnek, de már a kapcsolat és együttmüködés egy bizonyos szintjéről lehet beszélni. A civil szféra ennek okát az önkormányzat kezdeményező kézségének hiányában látja, valamint a feladatféltést jelöli meg okként. Az önkormányzat szemszögéből nézve igényt támasztanak az öntevékeny szervezetek képviselőire a bizottságok munkájában, de amíg a szféra nem tud egy egységes érdeket képviselni és mindenki által elfogadott képviselőt kiállítani, aki tényleges érdekvédelemre van feljogosítva, a közös munka lehetetlen. A szervezetek nem mondhatók autonómnak, hiszen az alacsony tagdíjbevételek mellett a pályázatokból tudnak megélni, az elnyerésükért folyó versengésben lassan egymás vetélytársává válnak, hiányzik az együttműködés, a közös fellépés.

$\mathrm{Az}$ együttműködést mindenképpen segítné, ha a város kidolgozná civil koncepcióját. A település városfejlesztési koncepciójában ugyanakkor a civil szervezeteket számos esetben segítségül hívják, mint partnereket, közoktatási programokban, a szociális rendszer fejlesztésében, a városi közintézmények rekonstrukciójában, a 
kulturális élet és városarculat tervezése terén, a környezetvédelemben. Azonban a nonprofit szervezetek ennél szélesebb körủ feladatvállalásra képesek a település életének formálásában. Néhány példa a lehetőségek közül: esélyegyenlőség megteremtése, egészségmegőrzés, fogyatékos-rehabilitáció, kapcsolatépítés, fejlesztési koncepciók kidolgozása.

A nonprofit szervezetek bekapcsolódását a helyi társadalom ügyeinek intézésébe, az önkormányzati döntések előkészítésébe és véleményezésébe elösegítené, ha a jelenleg szétaprózódott helyi szervezetek összefognának, képesek lennének alulról megszervezni magukat és így egységes erőként partnerévé válni az önkormányzatnak. Ennek egyik módja, ha kerekasztalok szerveződnek. Ez a fajta egyeztető fórum viszonylag új jelenség hazánkban. Megyei szinten Baranyában már működnek kerekasztalok. 2004 márciusában a megyei közgyűlés elfogadta a civil stratégiát, s benne a civil szervezetek érdekképviseletének megteremtése céljából történő civil kerekasztalok létrehozásának ösztönzését. Kilenc civil kerekasztal alakult meg: az egészségügyi, a szociális, a kulturális, az oktatási, a nemzeti és etnikai kisebbségi, a gyermek, ifjúságvédelmi és sport, a környezetvédelmi és területfejlesztési, az idegenforgalmi, valamint a közrend és közbiztonsági. A civilek közötti együttmüködés kifejezetten az egyes szakterületeken, közös pályázatoknál jelenik meg. Az önkormányzat pedig tanácsadással próbálja ezt a folyamatot erősíteni. Az önkormányzat számára azért is fontos a civil szervezetek szakmai tapasztalatának megjelenése a döntéshozatalban, mert az segítheti az önkormányzati feladatellátást, működése bővitését, és javíthatja hatékonyságát. A feladat-ellátási szerződések pedig azt mutatják, hogy a civilek hatékonyabban, költségkímélőbben tudják ellátni ezeket a feladatokat, ami a társadalomhoz való közelségüket mutatja. A nonprofit szervezetek oldaláról nézve a kerekasztalok létéről feltett kérdésekre nemleges válaszok érkeztek, a többség nem vesz részt, illetve nem is tud azokról. Illetve több esetben fogalmazódott meg, hogy ezek a kezdeményezések az önkormányzat oldaláról indultak el és ebben ők nem hisznek. A müködésükkel kapcsolatban is több szervezetnek vannak kétségei, a legéletképesebbnek a szociális kerekasztalt tartják. Mint ahogy minden kezdeményezés a civil szférán belül kezdetben több szervezetet vonzott, ma már az alakuló ülésen megjelent szervezetek töredéke működik csak együtt ebben a formában.

A Pécsi Ifjúsági Kerekasztal a városban működő gyermek és ifjúsági korosztályokkal foglalkozó civil szervezetek, diákönkormányzatok, felsőoktatási hallgatói önkormányzatok, valamint politikai ifjúsági szervezetek közötti érdekegyeztetés fóruma. Ezen intézményesült érdekegyeztetési fórum működtetését, valamint adminisztratív hátterének biztosítását a Baranya Ifjúságáért Kht. keretein belül foglalkoztatott ifjúsági referens végzi.

A Pécsi Ifjúsági Kerekasztal létrehozásának célja, hogy a városban a gyermek és ifjúsági korosztály érdekei, igényei megjelenjenek az önkormányzat ifjúságot érintő döntéseinek meghozatala során. A fiatalok reprezentációjának megteremtése eredményeképp kialakulhat az egységes ifjúsági érdekképviselet, a fiatalok egymás közötti párbeszéde elősegítheti, hogy az önkormányzat a konkrét kezdeményezéseket konkrét támogatások nyújtásával tudja segíteni. Pécs Önkormányzata többször jelezte nyitottságát a fiatalok felé, és most a civil szervezeteken, diák- és hallgatói önkormányzatokon, politikai ifjúsági szervezeteken a sor, hogy az önszerveződés útján létrejövő szervezeti erő alkalmazásával legyenek partnerek, ha kell, nyomásgyakorló Iényezők az önkormányzat mellett vagy akár azzal szemben is.

A pécsi kistérségben 2004 folyamán megalakult a Kistérségi Civil Fórum, amely " térségben található területfejlesztési tevékenységet folytató szervezeteket tömöríli magába, közös képviselőjük a civil szervezeteket érintő kérdésekben tanácskozói joggal bír a kistérségi ügyekben. A Fórum iránt a nyolc-kilenc lelkes szervezeten kívuil az érdeklődés nagyon alacsony. Sajnálatos módon a szervezetek többsége ezzel a lehetőséggel sem él.

Az önkormányzatok amellett, hogy kapcsolatot építhetnek ki szervezetekkel, segíthetik működésüket, maguk is létrehozhatnak nonprofit szervezeteket. A DélDunántúlon magas az önkormányzatok alapítási aktivitása. Azonban ez az aktivitás a Pécsi kistérségben a községeket nem jellemzi.

Az önkormányzat részt vehet alapítóként alapítvány, közalapítvány és egyesulet létrehozásában. A pécsi kistérségben a települési önkormányzatok 75\%-a nem vett részt nonprofit szervezet alapításában. Két önkormányzat egy-egy, két önkormányzat két-két szervezet létrehozásában müködött közre. Pécs önkormányzata közel 50 szervezetet alapított részben vagy egészben, 23 alapítványt, öt közhasznú társiságot hívott életre. Négy alapítványt és 11 közhasznú társaságot, mint társalapító hozott létre. Egerág öt egyesületet és egy közalapítványt, Görcsöny és Bakonya egy egyesületet és egy közalapítványt, Orfü és Gyód egy közalapítványt, Keszü egy egyesületet alapított.

Az önkormányzatok több okból alapítanak maguk is szervezetet. Ennek oka lehet a hatékonyabb ellátás és költségcsökkentés, az önkormányzatokra jellemző rengeteg formaság kikerülése.

7. táblázat: A Pécsi kistérség önkormányzatainak száma, akik együttmüködési megállapodásban állnak nonprofit szervezettel, 2004

\begin{tabular}{|l|c|}
\hline Tuyüttmúködési megállapodások számokban & Önkormányzatok száma \\
\hline Nincs együttmüködése nonprofit szervezettel & 15 \\
\hline 1 szervezettel & 3 \\
\hline 2szervezettel & 2 \\
\hline 3 szervezettel & 1 \\
\hline 5 szervezettel & 2 \\
\hline 10 szervezetnél többel & 1 \\
\hline Osszesen & 24 \\
\hline
\end{tabular}

Forrás: kérdōíves vizsgálat

$\mathrm{Az}$ együttműködési megállapodások száma a településmérettől is függ. $\mathrm{Az}$ együttműködési megállapodás a nagyobb településeken jellemző inkább, a kisebb községekben kevésbé. Azonban ez a megállapítás nem minden esetben igaz, kivételt képeznek ez alól az 1001 és 1500 lakossal rendelkező települések. Ugyancsak kitűnik az. 501 és 1000 lakossal rendelkezỏ községek köre. 
8. táblázat: Azon önkormányzatok száma, akik együttműködési megállapodást kötöttek nonprofit szervezetekkel, településméret alapján, 2004

\begin{tabular}{|l|c|c|c|c|c|c|}
\hline \multirow{2}{*}{$\begin{array}{l}\text { Lakónépesség sze- } \\
\text { rinti település kate- } \\
\text { góriák }\end{array}$} & \multicolumn{6}{|c|}{ Az önkormányzatoknak együttmúködési megállapodásuk van } \\
\cline { 2 - 7 } & Nincs & $\begin{array}{c}\text { Egy szerve- } \\
\text { zettel }\end{array}$ & $\begin{array}{c}\text { Két szerve- } \\
\text { zettel }\end{array}$ & $\begin{array}{c}\text { Három } \\
\text { szervezettel }\end{array}$ & $\begin{array}{c}\text { Öt szerve- } \\
\text { zettel }\end{array}$ & $\begin{array}{c}\text { Több, mint tíz } \\
\text { szervezettel }\end{array}$ \\
\hline $1-250$ & 5 & - & - & - & - & - \\
\hline $251-500$ & 3 & 2 & 1 & - & - & - \\
\hline $501-1000$ & 2 & - & 1 & 1 & 1 & - \\
\hline $1001-1500$ & 4 & 1 & - & - & - & - \\
\hline $1501-2500$ & 1 & - & - & - & 1 & - \\
\hline 2501 fellett & - & - & - & - & - & 1 \\
\hline Összesen & 15 & 3 & 2 & 1 & 2 & 1 \\
\hline
\end{tabular}

Forrás: kérdôives vizsgálat

A községi önkormányzatokra jellemző, hogy a sport, szabadidő és kultúra, településfejlesztés, polgárivédelem területén tevékenykedő szervezetekkel kötnek megállapodást. Továbbá megállapítható, hogy a településméret és a támogatott tevékenységi körök skálájának bővülése között párhuzam van. A nonprofit szervezetektől visszaérkezett kérdőivek alapján együttműködési szerződése van a községekben mủködő 38 szervezetből négynek. A következő feladatok ellátására: a cserkúti látványtó halasítására, közvetlen környékének gondozására, természetvédelemre, az Orfű magazin kiadására, kulturális rendezvények szervezésére, településfejlesztési feladatokra, idegenforgalmi célra, művészeti oktatás biztosítására. A pécsi önkormányzat több mint tíz szervezettel áll szerződéses partneri viszonyban, melyek megbízási szerződések alapján kapják az anyagi támogatást. A teljesség igénye nélkül néhány szervezet: Támasz Alapítvány, Máltai Szeretetszolgálat, Kerekvilág Jóléti Szolgálat Alapítvány, Fogd a Kezem Alapítvány, Ifjúságért Egyesület, Istenkúti Közösségért Egyesület, Civil Közösségek Háza, Pécsi Bányász Kulturális Egyesület, Közelítés Művészeti Egyesület, stb. Ezek a szervezetek jól kiépült infrastruktúrával és megfelelő anyagi bázissal rendelkeznek. A Pécsett tevékenykedő szervezetekkel az alábbi feladatok ellátására kötött együttműködést a város: kulturális programok, környezetvédelem, közművelődési feladatok ellátása, ifjúsági terület, cukorbetegek programjainak szervezése, kóbor állatok befogadása, hajléktalan gondozás, nyugdíjas korosztály programjainak szervezése.

A megyeszékhely több mint nyolcféle tevékenységi területet támogat, úgy, mint a szociális ellátás, környezetvédelem, sport, kultúra, oktatás, településfejlesztés, egészségügyi ellátás, kutatás.

Az önkormányzatok oldaláról érkező támogatás mértéke az évek során folyamatos növekedést mutatott, azon önkormányzatok száma pedig, akik egyáltalán nem támogatják a civil szférát, mára kilencre csökkent. 2004-ben a költségvetése 1-2\%-ának megfelelö összeget adott 12 önkormányzat, de ezen belül is nagyon nagy a szórás.

Az önkormányzattól érkező bevétel sok tényezőtől függ: a szervezetek társadalomban betöltött szerepétől, taglétszámtól, érdekérvényesítő képességeitől, kapcsolataitól és nem utolsó sorban az önkormányzat gazdasági helyzetétől. Ezen kívül meghatározó tényező a település típusa is, amit a táblázat egyértelmủen alátámaszt, hiszen a megyeszékhelyen a szervezetek közel kétharmada, míg a községekben kevesebb, mint fele nem részesül ilyen jellegü támogatásban. A legjellemzőbb támogatási összeg az 50000 és 500000 forint közötti, a falvakban minden harmadik, a városban minden ötödik szervezet kap ekkora támogatást.

9. táblázat: Pécsi kistérség önkormányzatainak a civil szférára fordított támogatása, 2004

\begin{tabular}{|l|r|r|r|r|r|}
\hline $\begin{array}{l}\text { A civil szférát } \\
\text { unyagilag támogató } \\
\text { Unkormány-zatok }\end{array}$ & $\begin{array}{c}\text { A település } \\
\text { lakosság } \\
\text { száma }\end{array}$ & $\begin{array}{c}\text { A támogatás hány } \\
\text { százalékát teszi ki } \\
\text { a költségvetés-nek }\end{array}$ & $\begin{array}{c}\text { A támogatás } \\
\text { összege } \\
\text { (ezer forint) }\end{array}$ & $\begin{array}{c}\text { Támogatott } \\
\text { szervezetek } \\
\text { száma }\end{array}$ & $\begin{array}{c}\text { Egy szervezetre } \\
\text { jutó átlagos támo- } \\
\text { gatás (ezer forint) }\end{array}$ \\
\hline Abaliget & 637 & $0,09 \%$ & 120 & 1 & 120 \\
\hline Bakonya & 401 & $1,44 \%$ & 838 & 5 & 167,6 \\
\hline Baksa & 765 & - & 800 & - & \\
\hline Cserkút & 430 & $3,6 \%$ & 3194 & 10 & 319,4 \\
\hline Egerág & 1004 & - & 3500 & 6 & 583,3 \\
\hline Görcsöny & 1726 & $0,5 \%$ & 1300 & 4 & 325 \\
\hline Gyód & 618 & $0,9 \%$ & 600 & 1 & 600 \\
\hline Keszü & 1024 & $0,7 \%$ & 200 & 1 & 200 \\
\hline Kozármisleny & 4247 & 3,0 & 14672,5 & 13 & 1128,6 \\
\hline Kökény & 566 & $1,8 \%$ & 900 & 2 & 450 \\
\hline Ocsárd & 430 & $2,0 \%$ & 1000 & 1 & 1000 \\
\hline Orfü & 761 & $1 \%$ & 2300 & 5 & 460 \\
\hline Pécs & 158942 & $2,0 \%$ & 600000 & 350 & 1714 \\
\hline Péllérd & 1984 & $0,019 \%$ & 5230 & 13 & 402,3 \\
\hline Pogány & 1083 & $2,0 \%$ & 300 & 10 & 30 \\
\hline Romonya & 423 & $0,07 \%$ & 230 & 1 & 230 \\
\hline Szalánta & 1178 & $9 \%$ & 1350 & 9 & 150 \\
\hline
\end{tabular}

Forrás: kérdő́ives vizsgálat

A támogatást nyújtó önkormányzatok fele a településen betöltött szerepkör alapján választja ki a támogatottak körét, egynegyedük egyedi kérelmek alapján dönt. Vannak olyan települések, ahol a két szempontot egyszerre veszik figyelembe, de eltekintve egy-két példától, nem pályáztaták a szervezeteket a támogatásokért. Amikor már kiválasztották a szerencsés szervezetek körét, a támogatás összegszerủ megállapításánál megint csak a helyi társadalomban betöltött szerepkör a meghatározó, néhány esetben számít még a rászorultság. Érdekes módon az önkormányzatok egyetlen egy esetben sem döntöttek a szervezetek taglétszáma alapján, annak ellenére, hogy hazánkban az önkormányzatok az esetek többségében ezt a tényezőt tartják a helyi társadalomban betöltött szerep mellett mérvadónak. Ezen az alapon támogatják általában a nagy társadalmi bázissal rendelkező, szabadidő és sportegyesületeket.

A kérdőívekből az is kiderül, hogy milyen tevékenységű szervezeteket támogatnak inkább az önkormányzatok és melyeket kevésbé. A leginkább, az önkormányzatok több mint fele által támogatott a sport és a kultúra. A polgárvédelem, környezetvédelem, közbiztonság minden harmadik támogatást nyújtó által részesül anyagi hozzájárulásban. Kevésbé jellemző az oktatással, egészségüggyel, szociális ellátással, vallási célzattal alapított szervezetek segítése. 


\begin{tabular}{|l|c|c|c|}
\hline \multirow{2}{*}{ Nem anyagi támogatás formája } & \multicolumn{3}{|c|}{ Támogatásban részesüló szervezetek \%-os eloszlása } \\
\cline { 2 - 4 } & Pécsi kistérség & Pécs & Községek \\
\hline Ingyenes iroda, illetve ingatlan használat & 18,6 & 11,7 & 40 \\
\hline Kedvezményes iroda, illetve ingatlan bérlet & 2,8 & 2,7 & 2,9 \\
\hline Postaköltség, telefon, telefax, számítógép-használat & 6,2 & 4,5 & 11,4 \\
\hline Jármühasználat & 1,4 & 0 & 5,7 \\
\hline Könyvelés, nyilvántartás & 0,7 & 0,9 & 0 \\
\hline Szakmai, szellemi segítségnyújtás & 7,6 & 6,3 & 11,4 \\
\hline Egyéb & 2,8 & 0 & 5,7 \\
\hline
\end{tabular}

Forrás: kérdőíves vizsgálat

Az önkormányzatok nem csak anyagi szempontból támogathatják a településén éló nonprofit szervezeteket, hanem egyéb módon is, erre mutat alternatívákat a 10. táblázat. A nem anyagi jellegü támogatások közül az önkormányzatok leginkább ingyenes irodahasználattal segítik a szervezetek munkáját. A községekben ebben az esetben is tapasztalható az önkormányzat kiemelt figyelme a szervezetek felé, hiszen minden harmadik részesül ingyenes irodahasználatban, szakmai segítséggyújtásban, postaköltség- és telefon támogatásban.

\section{Összegzés}

Az általunk vizsgált kistérség településein található civil szféra fejlődésnek indult, a rendszerváltás óta eltelt néhány évben példaértékủ számbeli gyarapodáson ment keresztül. Ez a fejlődés és a helyi lakosság öntudatra ébredése nem csak a szervezetek mennyiségi gyarapodását jelentette, hanem minőségi értelemben vett fejlődését is, amelynek jelei az elmúlt öt-hat évben jelentkeztek leginkább. Az interjúk során gyakran elhangzott az a mondat, amely a Pécs és környéki civil szférát erősnek nevezte, de széthúzónak. Ez a két tulajdonság alapvetően meghatározza magát az egész nonprofit szektort - nem csak a vizsgált területet. Valóban igaz az a kijelentés, hogy egy erős, öntudatos szektorral állunk szemben Pécs és a környező falvak területén, azonban ennek alapját nem maga a szervezetszám, hanem az aktívan működő, alulról szerveződő közel félezer szervezet szolgálja. Ahol a közösségek vezetői és tagjai páratlan értékủ társadalmi tőkével, szervező kézséggel és tenni akarással jellemezhetőek. Erre az erős helyi társadalmi létre az önkormányzatok a térségben jól reagálnak, elindult a kapcsolatépítés a két szektor között. Bár a kitűzött cél - a két fél partneri kapcsolata - még messze van, de számos kedvező jel mutatkozik, mint a formálódó kerekasztalok, civil ügyekkel kapcsolatos bizottságok felállítása, megyei szinten civil koncepció, civil referens. Azonban a probléma a két szektor között alapvetően az, hogy mind a kettő a másikra vár, a másiktól várja azt, hogy az idomuljon hozzá. Az önkormányzat tényleges partnereket vár, olyan vitapartnereket, akiket a civilek választottak és elfogadják őket, legitimitást adtak nekik. A civil szervezetek viszont az önkormányzat nagyobb kezdeményező készségét hiányolják, sokkal több segítséget várnak el, mint az talán indokolt lenne.
Ugyanakkor a civil vagy nonprofit szektor akkor válhat a piaci és állami szféra mellet az ún. harmadikká, ha rendezi sorait, legalább tevékenységi körök mentén összefog, és együtt képviseli érdekeit a helyi társadalmak fejlődése érdekében. Hiszen csak így tud érvényesülni a civil kontroll és így válik demokratikussá a társadalom. A szervezetek egy része azonban sajnálatos módon, nem tud a településükön működő szervezetekről, nincs tisztában a szféra lehetőségeivel, lehetséges szerepével és nem a kornak megfelelő kihívásoknak próbál megfelelni (Nárai M. 2003; 114). Ugyanakkor a Pécsi kistérség civil szektorán belül az aktív és tevékenyen együttműködő szervezetekben nagy lehetőségek és feladatok rejlenek, a szféra fejlődése rajtuk múlik.

\section{Jegyzetek}

1990. évi LXV. számú a helyi önkormányzatokról szóló törvény.

A kutatás statisztikai adatgyüitését megnehezíti az a tény, hogy 2000 elốtti adatok a maitóle lééró Szentlổrincet és a környező községeket is magába foglaló kisterrséget jellemeznek Pécsi kistérség név alatt. A kistérségek megállapitásáról, lehatárolásáról és megváltoztatásának rendjéról szóló 244/2003 (XII.18.) Korm. rendelet az előzỏekhez képest, felülvizssálat eredményeként 18 új kistérség létrehozását valósította meg, igy jelenleg összesen 168 kistérség fedi le az ország területét. 2004 január elsejével Szentlớrinc és környezó települései kiváltaka a Pécsi kistéréégbỏl és önálóló területi egységet képeztek. A vizsgálat során a 2004 óta létezó Pécsi kistérség területén müködő nonprofit szervezetekre terjesztettük ki kutatásunkat.

A települések nyilvántartása a nonprofit szervezetek számát tekintve jelentôsen eltérnek a KSH által adott listától. Az eltérések: Bosta: KSH: 3, önk.: 0, Abaliget: KSH 9, önk:. 4, Nagykozár: KSH 4, önk.: 0, Egerág: KSH:7, önk:10, Romonya: KSH: 1, önk.: 0, Pogány KSH: 9, önk.:3, Ócsárd: KSH: 2, önk.:1, Pellérd: KSH 10, önk.:13, Cserkút: KSH:5, önk.: 10, Orfü: KSH:9, önk,:8, Bakonya: KSH 3, önk.:6, Görcsöny: KSH:4, önk.:5, Pécs: KSH:1417, önk.:425.

A KSH 2003-as statisztikája alapján, Kovácsszénáján három szervezet mủködött, ma már tudjuk, hogy egy közülük megszünt.

1000 lakosra jutó szervezetszám országosan 4,7, Baranya megyében 4,3.

Figyelembe kell venni ennél az adatnál azt a tényt, hogy az önkormányzatok visszaküldött kérdốvei alapján 10 településen nincs nonprofit szervezet, tehát kapcsolattartóra nincs szükség.

Azonban a szerepkörök összeolvadása felveti azt a kérdést, hogy ilyen esetben mennyire érvényesül a civil szervezetek kontrollja, a társadalmi közvetító szerep.

\section{Felhasznált irodalom}

Az önkormányzatok és a nonprofit szervezetek kapcsolata 2000 (2002) KSH Budapest

Honcz J.-Kuti É.-Locherné KeLÉDi I.-MÉsZÁros G.-SEBestény I.: Nonprofit szervezetek Magyarországon,19932000 Budapest: Központi Statisztikai Hivatal,

Aalogh B.-BonCZ J.-Kuti É.-Mészáros G.-Sebestény I.-Telegdi L.: A Nonprofit szektor föbb statisztikai jellemzöi, 2001, 2002 Budapest : Központi Statisztikai Hivatal,

Hourdieu, P. (1999): Gazdasági tôke, kulturális tóke, társadalmi tơkke. In: Angelusz R.(szerk) 1999: A társadalmi rétegződés komponensei: Budapest: Új Mandátum Kiadó, 156-178.

CATÁRI B.(1996): A magyarországi kistérségek néhány jellegzetessége. Kistérségi folyamatok és területfejlesztési politika (Részletek). Falu város régió, 10. sz. 6-8.

GIGÉnY P.- KáKAI L.(2001): Köztes helyzet!? A civil szervezetek és az önkormányzatok kapcsolatában az ezredforduló Magyarországán. Budapest: Miniszterelnöki Hivatal Civil kapcsolatok Főosztálya

I NYEDI Gy. (1996): Regionális folyamatok Magyarországon az átmenet idöszakában. Ember. Település. Régió. Budapest: Hilscher Rezső Szociálpolitikai Egyesület. 82.

GAspár M. (1999): Magad uram... A civil önkormányzás körvonalai In: Együttmủködési lehetőségek a civil szervezetek es a helyi önkormányzatok között. Dem Net Könyvek 3., Hálózat a Demokráciáért Program pp. 189-197.

IIARś̃NYI L. (1997): Az állam és a nonprofit szektor. INFO - Társdalomtudomány, 42. 17-21.

Кџт É. (1991): A nonprofit elméletek tanulságai és a nonprofit elmélet tanulságai Magyarországon. Közgazdasági Szemle, I. 18-30

Kuт E. (1997): Van-e válaszunk a nonprofit szektor fejlödésével összefüggö kihívásokra? INFO - Társadalomtudomány, 42. 7-15

Kum É. (1998): Hivjuk talán nonprofitnak _.. - Budapest: Nonprofit Kutatócsoport.

I f́A K. (szerk.) (1998): Civil a Pályán - Helyi Társadalom Kutató Csoport, 110 
Márfi A. (1988): Baranya megye egyesületeinek vizsgálata (1915-1950). In: Szita László (szerk) 1988: Baranyai Helytörténetírás 1987-1988. Pécs: Baranya Megyei Levéltár Évkönyve. 251-288.

Márfi A (1989): Baranya vármeove egyesületei (1867-1914) In: Szita László (szerk) 1989: Baranyai Helytörténetírás 1985-1986. Pécs: Baranya Megyei Levéltár Évkönyve. 133-161.

Márfi A. (1989): Pécs szabad királyi város dualizmus kori egyesületeinek vizsgálata. In: Szita László (szerk.) 1989: Baranyai Helytörténetírás. Pécs: Baranya Megyei Levéltár Évkönyve. 193-214.

NÁrAI M. (2003): Civil szervezetek egy kisváros életében. TÉT XVII. évf. 2003/1. 91-115.

SZÁz A. (2003): A kormány civil stratégiája. Esély, 1.pp. 108-116

KSH 2003. évi gyorsjelentés a nonprofit szervezetekröl.
GÁSPÁR GABRIELlA

\section{Női jogok és a leánynévhasználat a XIX. század első felében}

Évekkel ezelött egy kutatás keretében elvégeztem az 1814-1832 közötti időszakban megjelent magyar folyóiratokat megrendelők társadalmi összetételének vizsgálatát. /Gáspár Gabriella, Agroinform 2002./ Tizenkilenc év előfizetői listáit dolgoztam fel szociológiai és történészi módszerekkel. A mintegy négyezer rekord elemzése során az előfizetők rendi, vallási, foglalkozási, szakmai megoszlását, továbbá a lakóhelyet és az előfizetés éveit vizsgáltam.

A teljes olvasóközönség természetesen többszöröse a 3842 előfizetőnek; $k b$. 10-15 ezer személyre tehető azok köre, akiket elértek ezek a folyóiratok. Minden olyan családban, ahol a férfi előfizette valamelyik kiadványt, legalább egy művelt nővel (felesége vagy lánya) számolhatunk, akiknek egyharmada talán a tudományok iránt is mutatott érdeklődést, fele pedig a kultúra iránt általában, így becslés alapján kb. 1- 2 ezer nő kerülhetett az olvasóközönségbe. Ezen nők rendi összetétele valószínűleg hasonló szerkezetü, mint azoké, akiknek nevét és társadalmi állását ismerjük az előfizetői listák alapján. A XIX. század elején megjelenő folyóiratokat önjogon megrendelő nők összetétele nagyjából megfeleltethető a korabeli kulturális elitbe tartozó nők mintájának. Ebben a szemléletben az előfizetők között szereplő 80 nő nem is annyira kevés.

A kutatás során vizsgált három folyóirat közül a Tudományos Gyüjtemény müködött legtovább (1817-1841), s a 25 év alatt a lap eltartotta önmagát. Nem mondható el ez sem a nyolc évig létező a Felső-Magyarországi Minerváról (1825-1832), sem a legkorábban induló, de csak öt évig fennmaradt Erdélyi Múzeumról (18141818) sem. A kutatás során azonban a Tudományos Gyủjteményt is csak 1832-ig -az attfedés éveiben vizsgáltam -, egyrészt, mivel az első reformországgyủlés kezdő éve (1832) kirajzol egy fajta politikai határt, másrészt, mert a 30-as években megváltozott a hazai sajtó természete. Tehát a vizsgált 16 évben a Tudományos Gyủjteménynek 3055 előfizetője volt, a Felső-Magyarországi Minervának 8 év alatt 581, az Erdélyi Múzeumnak pedig az 5 év alatt 595 .

A 81 előfizető nő a következőképpen oszlik meg a három folyóirat között:

Erdélyi Múzeum (1814-1818): 33

Tudományos Gyüjtemény (1817-1832]): 41

Felsö-Magyarországi Minerva (1825-1832): 12 